\title{
Judicial Administration during Ancient Period in India
}

\author{
V. Sathiya* \\ Assistant Professor of History, Erode Arts and Science College (Autonomous), \\ Erode, Tamil Nadu, India; thangamlavan@yahoo.co.in
}

\begin{abstract}
Justice is the first virtue of social institutions as truth is of systems of thought. A theory, however, elegant and economical, must be rejected or revised if it is untrue: likewise laws and institutions no matter how efficient and well arranged, must be reformed or abolished if they are unjust. Ubiquitous divinity was universally associated with the unfettered ruler, the king in olden days. The evolution of the Hindu system towards a system having a legislative aspect was insistently warning the king that a judgment is not just unless it is given in conformity with the precepts of the sastras. The Vedas are the main source of laws. The regular word for law or custom in the Rig-Veda is Dharma.
\end{abstract}

Keywords: Danda, Dharmasthiya, Dharmasthana, Gramyavadin, Kantakasodhana, Madhyamasi, Mantriparishad, Mahadandanayaka, Mahakshapatalika, Steya, Vyavahara, Wergild

\section{Introduction}

This paper highlights the roots of judicial administration in India during the ancient period. Ever since the birth of society, legal systems have been one of the most important quests of human endeavour. In ancient India, the term 'legal' and 'protection' had invariably been associated with the term 'Dharma', which passed through several transactions of meaning in its most prominent significance. Theft, burglary, highway robbery and cheating are among the crimes recorded. A cattle lifting at night was very frequent. Tying the criminal to a stake was a common form of punishment. Criminals were subjected to fire and water ordeals. It also narrates the codes of law during the reign of different dynasties from the Vedic age. It also focuses on the various kinds of civil and criminal crimes and the punishments given by the different rulers in India during the ancient period.

It is quite interesting to pin-point here that justice in India has been extolled as the very embodiment of God itself whose sole mission is also to uphold justice, truth and righteousness. In ancient times, more emphasis was laid on search for truth. The Indian Epic Mahabharata says that the King who is also the one who dispenses justice should not deviate from the path of truth, and that he should be a cultured person with an intellectual bent of mind ${ }^{1}$.

Dharma is essential because it promotes individual security and happiness as well as the stability of the social order since a state of nature without law is equivalent to anarchy. The fear of anarchy led to the elevation of dharma to divine status. To further safeguard the position of dharma another concept was introduced that dharma is protected by danda (punishment). Different types of punishments are stated by Kautilya in Arthasastra ${ }^{2}$. The rules of dharma were formulated by the law-makers. The concept of dharma rooted in caste was extended to every aspect of human activity. It was logical therefore that the equality of all before law was not recognized in those days.

\section{Objectives}

This Research work has the following objectives: 
- To explain the judicial systems prevailed in ancient India.

- To identify the growth of legal systems introduced by various rulers.

- To know the various punishments for different crimes.

\section{Methodology}

The methods of this research are both descriptive and analytical including the study of documents drawn from Tamil Nadu archives, Connemara library, University of Madras Library are arranged chronologically and presented.

\section{Early Vedic Period}

The ancient people had laws and customs but without lawyers and judges. Later on the habit of writing rules on the palm leaves, terracotta, carving pictures on walls started. During the early Vedic period the customs and the traditions were taken as the law of the land ${ }^{3}$. In the primitive days punishments were given like eye for eye, teeth for tooth and during wergild the punishments were given through fines. Such fines were given as compensation to the families of the victim. In madhyamasi (later) period the punishments were given through arbitration or trial.

\section{Vedic Period}

The justice was given in accordance to the law, which even the king could not violate. Some of the crimes mentioned in the Rig veda the earliest text of that time include theft, burglary, high-way robbery etc., Smritis generally enumerate 18 causes of disputes such as debts, sales without adequate title, fixing of boundaries, partition, non-payment of wages, breach of contract, partnership, adultery, violence, slander, larceny, robbery etc ${ }^{4}$.

We came across the fact that, those accused or suspected of theft had to prove their innocence by oath or ordeal or sometimes both were combined. Manu mentions only two kinds of ordeal, fire and water. It has been mentioned that if a debtor failed to repay his loan he has to serve a period of servitude to the creditor. The system of arbitration and the system of taking oaths in matter of doubt was also in practice. Among the various crimes mentioned in the Smritis and the other literary works, 'Steya' or theft was the commonest. The Rig Veda often mentioned about the thieves (Tayu or Steya) and robbers (Taskara) in several hymns ${ }^{6}$.

\section{Later Vedic Period}

In later Vedic period the idea of imperialism came into existence. It is proved by the terms Adhiraj, Rajadhiraj,
Samrat, Ekarat, etc. At the same time some conditions were imposed on the king. Dharma was considered to be the real sovereign of the country and the king was merely required to enforce the same. The king was made to depend on his ministers. Then another check was put on the king by the formation of sabha and samiti. The sabha also acted as a court of justice.

The judicial system was advanced beyond the primitive system of 'eye for eye and tooth for tooth'. The accused were let off with penalties like the price of 100 cows (satadaya,). The village judge was known as Gramyavadin( $T$ aittiriyasamhita) ${ }^{7}$. As in the early Vedic period the King was the fountainhead of all powers. But the two councils 'Sabha' and 'Samiti' had gradually lost their importance. In some verses of Jivagribh of Rig Veda and the Ugras of the Upanishads there is a mention about the existence of a well administrated police system.

The King is the fountainhead of justice. He should possess the sense of impartiality; otherwise he will not be able to discharge his judicial duties properly. At the village level petty cases were decided by Gramyavadin or village judge with the help of his court ${ }^{8}$. Ancient Indian jurists devoted a great deal of attention to evolving a law governing the administration of justice. A code of conduct for judges concerned in the administration of justice, as well as provisions for punishment of officers committing offences in the course of such administration of justice, were provided by lawmakers such as Brahaspati, Narad and Manu'.

Unlike the Vedic Age, the Brahmanic or the Epic Age had the Justice officially administered. Cities were multiplied throughout India and had their judges, executive officers and police. The legal inequality was also prevalent due to the caste system ${ }^{10}$. Various forms of judicial organizations were present during the ancient period of which the court headed by the king was the highest court.

Other law-makers like Katyayana have also cited the existence of thieves in the ancient society. The Lawgivers had made some provisions to help the poor who stole for economic reasons. According to those laws any traveller in scarcity of food was permitted to take from another's land two sugarcane stalks, two mulakas or tubers, two cucumbers or melons, five mangoes or pomegranates and a handful of dates, corn or rice, wheat or horse gram.

\section{Legal Measures Under the Mauryas}

Megasthenes, a Greek traveler who visited India during the Mauryan regime had recorded in his work 'Indica' that there was no theft or robbery in that empire. But Kautilya 
in his work 'Arthasastra' had referred to the thieves as the pests of the society and suggested various steps to curb their activities ${ }^{11}$.

Megasthenes described, that the general honesty of the people was well attested by the fact that theft was a thing of rare occurrence. The code of punishment was severe mutilation for giving false evidence and death for injuring the royal artisan. Kautilya's Arthasastra described that the King was at the apex of the whole judicial system to which appeals could be made ${ }^{12}$. The four heads of law have also been mentioned in it.

They are as follows:

- Dharma : To give out what actually happened.

- Vyavahara : To rest on evidence.

- Charita : Customs and precedents.

- Rajacasana : Royal proclamation.

There were two types of law courts during the Maurya period called 'Dharmasthiya' or court of civil law and 'Kantakasodhana' or the court of criminal law ${ }^{13}$. The literary sources of the Mauryan period, both Indica of Megasthenes and Arthasastra of Kautilya describe that the penal code was very severe. The punishments like mutilation of limbs or death penalty was in practice ${ }^{14}$.

The Mauryan King was the head of the court at the capital city Pataliputra. Other than this court there was the court of Chief Justice assisted by four or five other judges to provide justice. In the local level, village assemblies acted as courts of law. The court building in the capital city was called as 'Dharmasthiyam' ${ }^{15}$. The punishments differed according to the severity of the crimes from fines, imprisonment, mutilation and death.

There were several local courts in towns of the Mauryan Empire. Three judges and three commissioners conducted the cases in these courts. According to Arthasastra, the State recognized the local usage, customs of people, castes, community, clan and family, every bye-law of the corporate bodies, guilds and organized non-political communities ${ }^{16}$. Therefore at last we come across the fact that the Mauryans gave importance to discuss the problem by Guild (a society of merchants).

\section{Judicial System Under the Guptas}

During the reign of Chandragupta II, the celebrated Chinese pilgrim, Fa-hien visited India. According to the Chinese pilgrim, the people of the Gupta kingdom were prosperous and happy. The king in his administration used no corporal punishment; criminals were merely fined according to the severity of their offences. Even for a second attempt at rebellion, the punishment was only the loss of the right hand. The local courts and separate councils were present where the cases were decided by the village elders or the experienced judges. The court of higher appeal was presided over by the King who was assisted in this task by other judges like 'Mahadandanayaka'(chief justice), 'Mahakshapatalika'(head of keepers of land record) ${ }^{17}$.

The 'Mahadandanayaka' had to perform both the duties of a judge as well as an army general. The 'Mahakshapatalika' was the keeper of records. The great poet of the Gupta era Kalidas mentioned about the officials named 'Dharmadhikaras' ${ }^{18}$. They were supposed to maintain the law and order in the towns and were expected to be well-versed in the scriptures of 'Dharma'. The judgement on any case was awarded based on the legal texts available those days, the then existing social customs and finally on the decision of the King. There is no evidence on the cases related to family affairs dealt by the king's court.

Compared to the Mauryas, the Gupta penal code was somewhat mild. Collection of fine was considered as an adequate form of punishment for violating the law of the state. The King continued to be the fountain head of all the powers during the reign of Vardhanas also. Hiuen Tsang, the Chinese traveler says that imprisonment was the most usual form of punishment under the Harsha period. Those sentenced imprisonment were often made to work on road and in public places so that it could have a deterrent effect on others. Mutilation of limbs was also restored to as a punishment. Usually the hands of the thiefs were mutilated. Banishment, another type of punishment was usually inflicted on the privileged classes. Death sentence was imposed on murderers, traitors, dacoits and persons guilty of heinous sex crimes ${ }^{19}$.

It was believed that a King who punished the innocent or let off the guilty incurred sin. The court of justice was called as 'Dharmasthana'. The decision by 'Vyavahara' (Vyavahara means proceedings in a court of law between two parties in which the violation of Dharma is established by effort) or judicial proof was arrived at after following the procedure. Some cases were judged summarily, without following all the steps of the legal procedure ${ }^{20}$.

Harsha was assisted in the administration by an advisory council called Mantriparishad. The districts had their own law courts. The village or grama was the lowest unit of administration and grameyaka was put in charge of it. The Mahattaras or the village elders formed an unofficial council to help the headman in the discharge of his duties. 
The popular panchayat courts tried all the civil and criminal cases.

Violent crime was rare, but the roads and river routes were exposed to brigands as Hieun - Tsang fall victim to them more than once. Criminal law was exceptionally severe. Imprisonment for life was the ordinary penalty for violation of the statute law and conspiracy against the sovereign; prisoners were not treated as human beings. But on festive and joyous occasions they were, however, released. The punishments were of cruel nature as mutilation of the nose, ears, hands or feet was inflicted as the penalty of serious offences. Sometimes the offenders were deported to another area. Ordeals by fire, water or poison were sometimes taken recourse to establish the innocence or guilt of a person. The severity of the criminal law acted as a deterrent to violation of law ${ }^{21}$.

Civil suits were decided by the village councils which had also jurisdiction over petty criminal cases during the reign of Rashtrakutas in India. The administration of justice was carried on by the king and his ministers in Deccan. But in practice, judicial powers were delegated to lower officers and village assemblies functioned as courts. The judges were called Dharmadhyakshas. Generally, oral and documentary evidences played a vital part in deciding a case, sometimes divya or ordeals were used in settling the issues. Ex-communication from the society and fine were different types of punishment meted out to the offender ${ }^{22}$.

\section{Conclusion}

This chapter explains the relationship between law and society and involves both the actual and ideal. It indicates that there is no law without society. In different periods like that of Mauryas, Guptas and Vardhanas different courts were prevalent. Their ultimate desire was to maintain the law and order in their provinces. During the period of Mauryas severe punishments were given for serious crimes. Whether Mauryas, Guptas and Vardhanas the ruler whoever may be, they wanted peace in their regions. The cases were decided according to the traditions and customs of Hindu caste under the panchayat system. The Raja was the highest court of appeal. There were civil and criminal courts at local level.

\section{References}

1. Agarwala BR. Our Judiciary. India: National Book Trust; 1996. p. 3.

2. Romila Thapar, Ancient Indian Social History. New Delhi: Orient Blackswan Pvt Ltd; 2010. p. 27.

3. Raychoudhary SC. Social, Cultural and Economic History of India. New Delhi: Surjeet Publications; 2007. p. 36.

4. Tripathi RS. History of Ancient India. Delhi: Mothilal Banarsidass Publication; 1967. p. 79.

5. Majumdar RC, editor. The Vedic Age. Bombay: BharathiyaVidya Bhavan; 1965. p. 439.

6. Rai K. Ancient India. Allahabad: KitabMahal. 1992. p. 34

7. Kumar R. Early History of Jammu Region (Pre- Historic to $6^{\text {th }}$ century A.D). Delhi: Kalpaz Publications; 2010. p. 197.

8. Sharma G. Ancient Judicial System of India. New Delhi: Deep and Deep Publications; 2008. p. 197.

9. Majumdar RC, editor. The History and Culture of the Indian People. Bombay: Bharathiya Vidya Bhavan; 1962. p. 364.

10. Williams JAV. History of India from the earliest times to the 6th century BC. London: The Grolier Society Publishers; 1906. p. 143.

11. Sastri KAN. A Comprehensive History of India-The Mauryas and Satavahanas. Calcutta: Orient Longmans Publication; 1957. p. 37.

12. Basham AL. The Wonder that was India. London: Sidgwick and Jackson;1956. p. 80.

13. Sinha P, Smriti. Political and Legal System: A Study. New Delhi: People's Publishing House; 1942. p. 64.

14. Sharma LP. History of Ancient India. New Delhi: Konark Publishers; 1996. p. 130-1.

15. Sinha P, Smriti. Political and Legal System: A Study. New Delhi: People's Publishing House; 1942. p. 54.

16. Sen SN. Ancient Indian History and Culture, New Age. New Delhi: International Publishers; 1988. p. 136.

17. Mani CM. A journey through India's past. Delhi: Northern Book Center; 2005. p. 67.

18. Sengupta NC. Evolution of ancient Indian Law. Calcutta; 1953. p. 58.

19. Raychoudhary SC. Social, Cultural and Economic History of India. New Delhi: Surjeet Publications; 2007. p. 150.

20. Tripathi RS. History of Ancient India. Delhi: Mothilal Banarsidass Publication; 1967. p. 304.

21. Ancient Indian History and Culture, New Age. New Delhi: International Publishers; 1988. p. 258.

22. Ancient Indian History and Culture, New Age. New Delhi: International Publishers; 1988. p. 411. 